\title{
THE VARIABILITY OF THE DIMENSIONS OF THE MERUS OF THE FIFTH PEREIOPOD IN THE AMPHIPOD GAMMARUS DUEBENI LILJEBORG, 1852
}

\author{
by \\ HENK G. DENNERT \\ Institute of Taxonomic Zoology (Zoölogisch Museum), University of Amsterdam, \\ The Netherlands
}

\begin{abstract}
The variability of the morphological character on which the distinction between a brackish water and a freshwater subspecies of Gammarus duebeni is based, viz. the ratio merus width/merus length in the fifth walking leg, is studied.

Evidence is given, that the merus dimensions only very partially can be correlated with the distribution and the ecology of $G$. duebeni. No clear clinal variation can be found in the merus dimensions in Europe.

The subspecies $G$. d. celticus is found only in inland waters in Ireland and Brittany; the subspecies $G$. $d$. duebeni is found in western and northwestern Europe, and in Canada, in brackish water habitats and in some freshwater localities. Evidence is given, that $G$. $d$. duebeni has invaded the latter freshwater localities only recently.
\end{abstract}

\section{INTRODUCTION}

Several papers have been published on the differences in physiology, morphology and ecology of more or less isolated populations of the amphipod Gammarus duebeni Liljeborg, 1852, in Europe.

Physiological differences were demonstrated by Sutcliffe (1967b, 1971 a \& b) and Sutcliffe \& Shaw (1968), who concluded that the populations of $G$. duebeni belonged to two different races. Some of the physiological differences, however, seemed to be phenotypic (Sutcliffe, 1971 a \& b).

Based on zoogeographical and morphological arguments, Stock \& Pinkster (1970) erected the two subspecies $G$. duebeni duebeni and G. duebeni celticus. The nominal subspecies $G$. $d$. duebeni was supposed to inhabit brackish waters, while the subspecies $\boldsymbol{G}$. $d$. celticus was described from fresh inland waters in Ireland and Brittany (France).

The main diagnostic character used by Stock $\&$
Pinkster (1970) was a morphological one, viz. the relative dimensions of the merus of the fifth pereiopod. At a merus length/merus width ratio with values $<2$ the animal belonged to the subspecies $G$. $d$. duebeni, while at a ratio $>2$ the animal belonged to the subspecies G.d. celticus (see fig. 1).

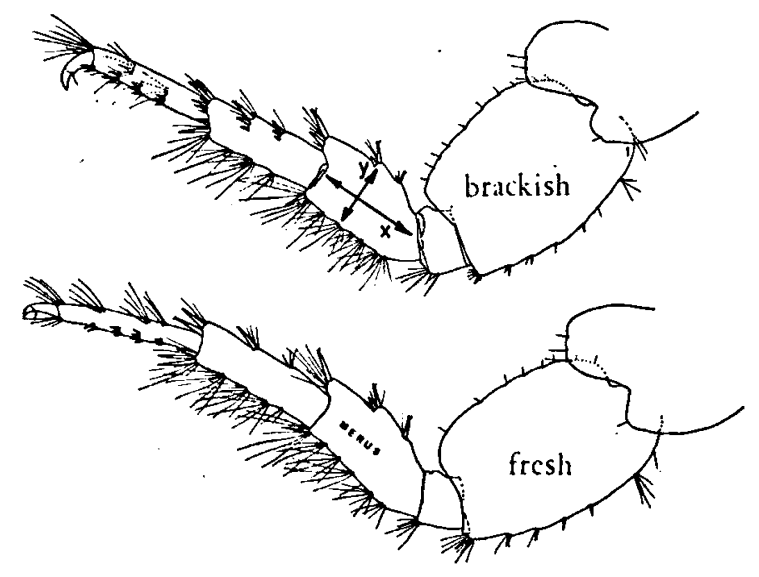

Fig. 1. The fifth walking leg ( $\hat{\jmath})$ of $G$. d. duebeni (top) and of $G$. $d$. celticus (bottom). Indicated is the merus width $(y)$ and the merus length $(x)$.

Sutcliffe (1972) reexamined the merus length/ width relation in $G$. duebeni, and found that he could indeed distinguish $G$. duebeni populations by comparing the merus width/merus length relationships of these populations. However, he also argued that the conclusion of Stock \& Pinkster (1970) and Pinkster et al. (1970) concerning the correlation between this morphological character and the (micro)habitat supposingly occupied by each of the subspecies (G. d. duebeni in brackish waters, and G. d. celticus in fresh waters) was invalid. Sutcliffe (1972) did not reject the two sub- 
species, but did raise the question whether the variation in merus dimensions was a clinal one.

All together the morphological arguments on which the freshwater and brackish water populations of $G$. duebeni were considered two subspecies (cf. Stock \& Pinkster, 1970, and Pinkster et al., 1970) are not too convincing. Furthermore, the statistical treatment of the data by Pinkster et al. (1970) was insufficient, as was already pointed out by Sutcliffe (1972).

In the first part of the present paper (section III) a thorough study is made on the variation in the merus dimensions in $G$. duebeni populations from Britain, Ireland, France, Norway, and Canada. The samples have been taken from such biotopes as rockpools, estuaries, fresh running waters, freshwater lakes, and the eulittoral zone of the Atlantic coast of Norway and Canada.

To support their theory on the origin of both subspecies, Pinkster et al. (1970) used some zoogeographical arguments in addition to the differences in morphology between the $G$. duebeni populations. These arguments were mainly based on the fact, that in Brittany $G$. duebeni and $G$. pulex (Linnaeus, 1758) were found only very rarely at the same station. From this observation Pinkster et al. (1970) concluded, that a severe interspecific competition between $G$. pulex and $G$. duebeni must exist. This conclusion was affirmed by laboratory experiments of Dennert (1974). Another conclusion drawn from the zoogeographical analysis was, that the subspecies $G$. $d$. celticus was inhabiting the upper reaches of rivers, while the subspecies $G$. $d$. duebeni was inhabiting the estuaries and other brackish water biotopes such as rockpools.

In order to get a clearer view on the zoogeographical arguments mentioned above, populations of $\boldsymbol{G}$. duebeni in Norway, the British Isles and Brittany have been reinvestigated.

In this context it is tried to elucidate two questions: (1) does a clinal variation exist in the merus dimensions, and (2) are the differences found in the merus dimensions correlated with the type of habitat in which the population is living?

The first question can be answered by comparing populations from the major part of the distribution area of $G$. duebeni in Europe, for answering the second question a detailed analysis of adjoining populations in different habitats (brackish versus fresh, spring zone versus middle reaches of a river) is necessary.

As a continuation of the microgeographical analysis carried out by Pinkster et al. (1970), also some attention will be payed to the distribution of $G$. duebeni and G. pulex in Scotland and Brittany.

\section{MATERIAL AND METHODS}

The animals used in this study are obtained from stations in Norway (see Dennert, 1973, and fig. 6), Scotland (see fig. 7), Brittany (see fig. 4), Ireland (see Pinkster ot al., 1970, table V), and Canada (see Steele \& Steele, 1969).

The animals collected were fixated in $4 \%$ formalin and thereafter stored in $70 \%$ aethanol. So all preparations were made from animals stored in aethanol. At the collection station temperature (and sometimes $\mathrm{pH}$ ) were determined, and a watersample was taken. Water analysis was carried out according to the methods described by Pinkster et al. (1970) and Van den Beld (1973).

In order to make a comparison possible between the results presented here, and those published by Pinkster et al. (1970) and Sutcliffe (1972), only males have been used for some statistical treatments. In each table it is indicated whether the results are based on males only, or on both sexes.

Microscopical slides of the 5th walking leg were made from the samples listed in table $I$, and from 48 freshwater samples from Brittany. For preparing the slides, both the left and right 5 th pereiopod of the animals concerned were dissected and mounted in Reyne's modification of Faure's medium.

For each animal also sex and cephalic length have been determined. This was done according to Dennert et al. (1969) and Van den Beld (1973).

All measurements have been taken with the aid of a Reichert (type MAK) stereomicroscope with an eyepiece micrometer (objective $4 \times$, eyepiece $10 \times)$. Two types of micrometers have been used: one with each unit corresponding with $0.037 \mathrm{~mm}$ (used for measuring the cephalic length), and a very accurate American Optical adjustable micrometer with each unit corresponding with 0.00225 $\mathrm{mm}$ (used in measuring the merus length and width). As far as possible calculations were done in micrometer units; values were thereafter converted into $\mathrm{mm}$ (to the nearest $0.01 \mathrm{~mm}$ ).

The relative dimensions of the merus of left and right leg were compared to see if they were statistically different. When tested with the T-test, according to Wijvekate (1963), only 15 out of the 
1089 males $(=1.4 \%$ ) examined from the Brittany populations show a significant difference $(P$ $>0.05$ ) between the left and the right leg. Such differences are often caused by regeneration of a (pa-tly) lost or damaged leg. In all samples, animals with such differences between left and right legs were excluded from the computations.

Of every sample the following data have been computed:

$\bar{c}=$ mean cephalic length

$\bar{C}=\log (\bar{c} .10)$

$\bar{x}=$ mean merus length

$\bar{X}=\log (\bar{x} \cdot 10)$

$\bar{y}=$ mean merus width

$\bar{Y}=\log (\bar{y} \cdot 10)$

$\bar{X} / \bar{C}, \bar{Y} / \bar{C}$, and $\bar{Y} / \bar{X}$.

In addition the regression lines of $C$ on $X$ and of $Y$ on $X$ have been calculated for each sample. The computations were done at an Olivetti P 102 desk computer, and on the Control Data Cyber 73 computer of the University of Amsterdam. Most computations were done according to Nie et al. (1970-1973).

The discriminant analysis used in section III was executed according to Nie et al. (1970-1973). The method was a stepwise one, selecting the variable which has the maximum $F$ for inclusion. This is equivalent to selecting the variable which minimizes Wilks' lambda.

III. COMPARISON OF THE MERUS DIMENSIONS OF $G$. DUEBENI POPULATIONS FROM DIFFERENT GEOGRAPHIC LOCALITIES

The analysis of the variation of the relative merus dimensions is carried out on 21 samples, listed in table I.

Of the animals of the pooled samples the relationships between cephalic length, and both merus length and width are determined. In fig. 2 it is shown, that there is a highly significant $(r=$ 0.975 and 0.953 , respectively, so $P<<0.001$ ) relation between the cephalic length on the one hand, and the merus length and width on the other hand. The steeper inclination of the regression line of the cephalic length on the merus width, compared with the regression line of the cephalic length on the merus length indicates that the merus growth is clearly allometric; the merus is growing faster in length than in width (Sexton, 1924).

Table I. List of stations with G. duebeni used in the analysis of section III, with remarks.

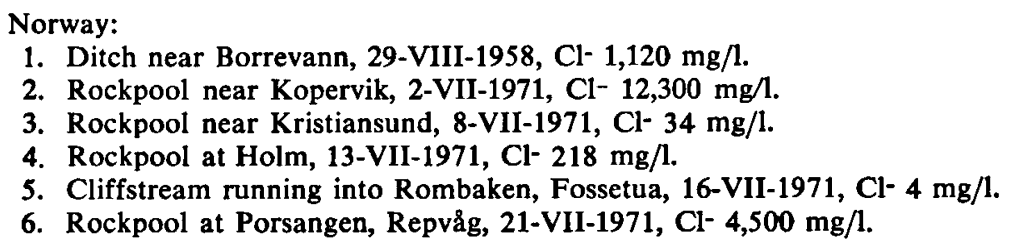

Canada:

7. Intertidal zone of Conception Bay, Holyrood, Newfoundland, 1973.

Scotland:

8. Craigock Burn, Rinns of Galloway, 2-IV-1972, Cl- $33 \mathrm{mg} / 1$.

9. Rockpool at Port Logan, Rinns of Galloway, 2-IV-1972, Cl- 7,800 mg/l.

10. Ballachroy, Argyll, 7-IV-1972, Cl- $15 \mathrm{mg} / \mathrm{l}$.

11. Glenbar, Argyll, 7-IV-1972, Cl- $15 \mathrm{mg} / \mathrm{l}$.

12. Rockpool at Ballochantay, Argyll, 7-IV-1972, Cl- $120 \mathrm{mg} / 1$.

13. Rivulet near Cambletown, Argyll, 7-IV-1972, Cl- $24 \mathrm{mg} / \mathrm{l}$.

14. Glen Breakerie, Argyll, 7-IV-1972, Cl- $20 \mathrm{mg} / \mathrm{l}$.

15. Strone Glen, Argyll, 7-IV-1972, Cl- $26 \mathrm{mg} / \mathrm{l}$.

Brittany:

16. Rockpool at Pte. St. Barbe, Le Conquet, 6-VII-1972, Cl- 1,450 mg/l.

17. Rockpool at Pte. de Brézellac, 12.VII-1972, $\mathrm{Cl}-1,450 \mathrm{mg} / \mathrm{l}$.

18. Tributary of the Aber W'rach, 13-X-1972, Cl- $15 \mathrm{mg} / \mathrm{l}$.

Ireland:

19. Lough Rea, Co. Galway, 18-XI-1969, Na $+22 \mathrm{mg} / 1$.

20. Rockpool at Black Head, Co. Clare, 18-XI-1969, Na+ $17 \mathrm{mg} / \mathrm{l}$.

21. Rockpool at Carnalea, Co. Down, 6-VII-1974, Cl- $10,800 \mathrm{mg} / \mathrm{l}$. 


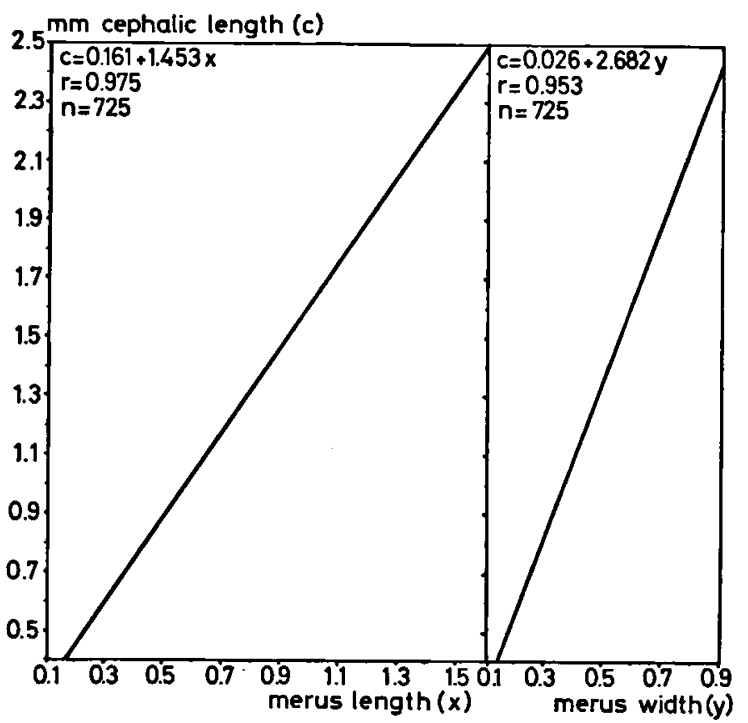

Fig. 2. Regression lines of cephalic length on merus length, and of cephalic length on merus width. The regression lines are computed from the original measurements of merus length and width of all animals (including juveniles) of the first 18 samples of table III.

Due to the allometric growth of the merus, the ratio $\bar{Y} / \bar{X}$ increases with increasing cephalic length (see table II). For comparison, in tables II and III the computed values of the $\operatorname{ratios} \bar{Y} / \bar{C}$ and $\bar{X} / \bar{C}$ are given as well. In table III (listing the fundamental data on the 21 samples concerned) the ratios are computed per sample, while in table II samples with approximately the same mean cephalic lengths are pooled. Table II shows, that there is a tendency that the ratios $\bar{X} / \bar{C}$ and $\bar{Y} \bar{C}$ increase with increasing ratio $\bar{Y} / \bar{X}$ but there is no strict correlation between these ratios.

Sutcliffe (1972) already brought forward, that the conversion of measurements into ratios leads to a loss of information. This is all the more true when the measurements are first converted into logarithmic funotions, and than converted into ratios. A simple example is given below:

$\frac{8}{4}=2$, and $\frac{12}{6}=2$, but

$\frac{\log 8}{\log 4}=\frac{0.9031}{0.6021}=1.4999$, and

$\frac{\log 12}{\log 6}=\frac{1.0792}{0.7782}=1.3868$

Hence in tables III and IV one ratio may be fluctuating, while another ratio based on the same measurements is increasing. This is no arithmetic error, but an illustration of the inaccuracy introduced in a biometrical analysis based on the comparison of ratios.

In table IV the samples of table III are rearranged according to the ratio $\bar{Y} / \bar{X}$. It appears, that no correlation exists between this ratio and the geographic locality. A rather strict correlation exists between $\bar{Y} / \bar{X}$ and the type of biotope. All the higher values for $\bar{Y} / \bar{X}$ are found in the brackish water biotopes (rockpools, estuaries, intertidal zone of the seashore), while all but two of the lower values are found in freshwater biotopes, i.e. rivers and lakes.

This observation seems to support the existence of two subspecies (Pinkster et al., 1970; Sutcliffe, 1972). However, some remarks should be made on this subject. Together with the ratio $\bar{Y} / \bar{X}$ in table IV also the ratio $\bar{x} / \bar{y}$ is given. The ratio $\bar{x} / y$ was, as is pointed out in the introduction, proposed as a diagnostic character by Stock \& Pinkster (1970). If this ratio is considered valid, one should decide that all animals in our samples (except those in sample no. 19) belong to the subspecies $\boldsymbol{G}$. $d$. duebeni. This would be in complete contradiction to the physiological, zoogeographical and ecological data available.

Sutcliffe (1972) proposed the discrimination value $\bar{Y} / \bar{X}=0.73$, based on samples classified on the forehand as belonging to $G$. d. duebeni or $G$. $d$. celticus. If this ratio is considered valid. one should consider all but two of the brackish water samples as $G$. $d$. duebeni, while five out of the eight freshwater samples should belong to $G$. $d$. celticus. Looking at table IV, one would be inclined to change the discriminating value of $\bar{Y} \bar{X}$ in upward direction. This would mean, that some typical brackish water samples will be classified wrongly as belonging to the subspecies celticus. Another example of the arbitrary nature of the discriminating value of 0.73 is found in table IV, samples 14, 15, 13 and 11. These samples with $\bar{Y} / \bar{X}$ values of $0.744,0.729,0.713$ and 0.662 , respectively, are obtained in Scotland from streams located nearby each other.

In table III the equations of the regression lines of $Y$ on $X$ are given for each sample. The initial and end points of these lines are indicated in fig. 3. For practical reasons (there would be too much lines closely together) each line is not individually drawn. In fig. 3 the line representing a log merus width $.10 / \log$ merus length $.10=0.73$ is also drawn. 
Table II. Comparison of the mean values of $\bar{Y} / \bar{C}, \bar{X} / \bar{C}$, and $\bar{Y} / \bar{X}$ of 48 samples of $G$. duebeni from Britanny, arranged according to increasing cephalic length.

\begin{tabular}{|c|c|c|c|c|c|c|c|c|c|}
\hline \multirow[t]{2}{*}{$N$} & \multirow[t]{2}{*}{$n$} & \multirow{2}{*}{\multicolumn{2}{|c|}{$\begin{array}{l}\text { Cephalic length (mm) } \\
\text { mean range }\end{array}$}} & \multicolumn{2}{|r|}{$\overrightarrow{\boldsymbol{Y}} / \vec{C}$} & \multicolumn{2}{|r|}{$\bar{X} / \bar{C}$} & \multicolumn{2}{|r|}{$\overline{Y / X}$} \\
\hline & & & & mean & range & mean & range & mean & range \\
\hline 2 & 43 & 1.14 & $1.10-1.19$ & 0.513 & $0.507-0.521$ & 0.769 & $0.761-0.774$ & 0.666 & $0.654-0.684$ \\
\hline 13 & 289 & 1.27 & $1.20-1.29$ & 0.539 & $0.491-0.555$ & 0.779 & $0.758-0.796$ & 0.690 & $0.648-0.710$ \\
\hline 21 & 439 & 1.35 & $1.30-1.39$ & 0.536 & $0.501-0.556$ & 0.786 & $0.767-0.811$ & 0.684 & $0.635-0.707$ \\
\hline 9 & 286 & 1.43 & $1.40-1.49$ & 0.554 & $0.534-0.565$ & 0.793 & $0.767-0.815$ & 0.699 & $0.670-0.708$ \\
\hline 3 & 101 & 1.54 & $1.50-1.59$ & 0.574 & $0.572-0.576$ & 0.816 & $0.802-0.827$ & 0.704 & $0.696-0.714$ \\
\hline
\end{tabular}

$N=$ number of samples; $n=$ number of males.

Table III. Meristic data of $G$. duebeni specimens from the 21 samples examined in section III.

\begin{tabular}{|c|c|c|c|c|c|c|c|c|c|c|c|c|}
\hline 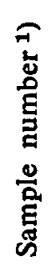 & 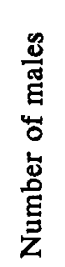 & 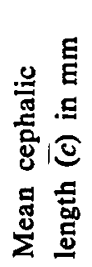 & $\begin{array}{c}0 \\
0 \\
10 \\
00 \\
11 \\
10\end{array}$ & 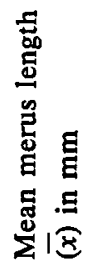 & 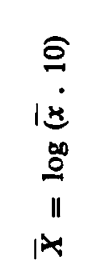 & 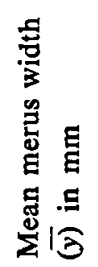 & $\begin{array}{c}0 \\
13 \\
13 \\
\stackrel{0}{11} \\
11\end{array}$ & $\underset{\mid N}{10}$ & 依 & 侪 & 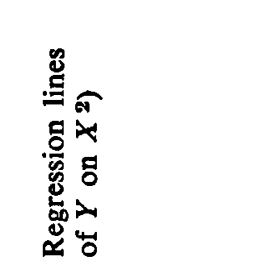 & 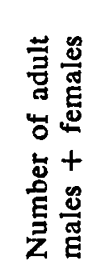 \\
\hline 1 & 20 & 1.20 & 1.079 & 0.74 & 0.869 & 0.43 & 0.633 & 0.805 & 0.614 & 0.728 & $X=0.252+0.978$ & 40 \\
\hline 2 & 12 & 1.79 & 1.253 & 1.13 & 1.053 & 0.62 & 0.792 & 0.8 & 0.6 & & 12 & 38 \\
\hline 3 & 5 & 1.79 & 1.253 & 1.17 & 1.068 & 0.66 & 0.820 & 0.852 & 0.654 & 0.768 & $X=0.029+1.253$ & 30 \\
\hline 4 & 9 & 1.42 & 1.152 & 0.86 & 0.934 & 0.56 & 0.748 & 0.811 & 0.649 & 0.801 & $X=0.104+1.104$ & 30 \\
\hline 5 & 17 & 1.51 & 1.179 & 0.99 & 0.996 & 0.59 & 0.771 & 0.845 & 0.654 & 0.774 & $=0.101+1.148$ & 39 \\
\hline 6 & 25 & 1.42 & 1.152 & 0.88 & 0.944 & 0.54 & 0.732 & 0.819 & 0.635 & 0.775 & $X=0.055+1.201$ & 43 \\
\hline 7 & 45 & 1.73 & 1.238 & 1.02 & 1.009 & 0.63 & 0.799 & 0.815 & 0.645 & 0.792 & $X=0.072+1.167$ & 64 \\
\hline 8 & 9 & 1.62 & 1.210 & 1.04 & 1.017 & 0.56 & 0.748 & 0.84 & 0. & 0. & $x=c$ & 44 \\
\hline 9 & 4 & 1.47 & 1.167 & 0.91 & 0.959 & 0.53 & 0.724 & 0.8 & 0.6 & 0.7 & $X=0$ & 19 \\
\hline 10 & 1 & 1.60 & 04 & 0.99 & 0.996 & 0.54 & 32 & 0 & 0 & & $x=0$ & 11 \\
\hline 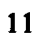 & 2 & 1.00 & 1.000 & 0.58 & 0.763 & 0.32 & 0.505 & 0.76 & 0.505 & 0.6 & $x=0$ & 6 \\
\hline 12 & 14 & 1.44 & 1.158 & 0.86 & 0.934 & 0.50 & 0.699 & 0.807 & 0 & 0.748 & .173 & 54 \\
\hline 13 & 1 & 1.09 & 1. & 0.65 & 0.813 & 0.38 & 0.580 & 0.7 & & 0.713 & 3) & 2 \\
\hline 14 & 2 & 1.80 & 1.255 & 1.16 & 1.064 & 0.62 & 0.792 & 0.848 & 0.631 & 0.744 & 3) & 2 \\
\hline 15 & 2 & 1.22 & 1.086 & 0.67 & 0.826 & 0.40 & 0.602 & 0.761 & 0.554 & 0.729 & $=0.176+1.085$ & 10 \\
\hline 0 & 54 & 1.3 & & 0.8 & & 0. & & & & & & 106 \\
\hline 17 & 8 & 1.41 & & 0.8 & 4 & 0.51 & & & & & 48 & 16 \\
\hline 18 & 40 & 1.40 & 1.146 & 0.80 & 0.903 & 0.42 & 0.625 & 0.788 & 0.545 & 0.692 & $X=0.259+1.029$ & 40 \\
\hline 19 & 24 & 1.6 & 1.205 & 1.20 & & 0.5 & & & & & & 43 \\
\hline 20 & 5 & 1. & & 0.7 & & 0.4 & & & & & 2 & 16 \\
\hline 2 & 18 & 1.16 & 1.064 & 0.72 & 0.857 & 0.44 & 0.639 & 0.806 & 0.601 & 0.746 & $=0.067+1.241$ & 20 \\
\hline
\end{tabular}

\footnotetext{
1) See table $I$.

2) $X$ and $Y$ representing each pair of separate measurements (on males and females), in which $X=\log (x .10$ ), and $Y=\log (y, 10)$.

3) Total number of individuals $\leqslant 5$, which makes too small a number to compute an accurate regression line.
} 


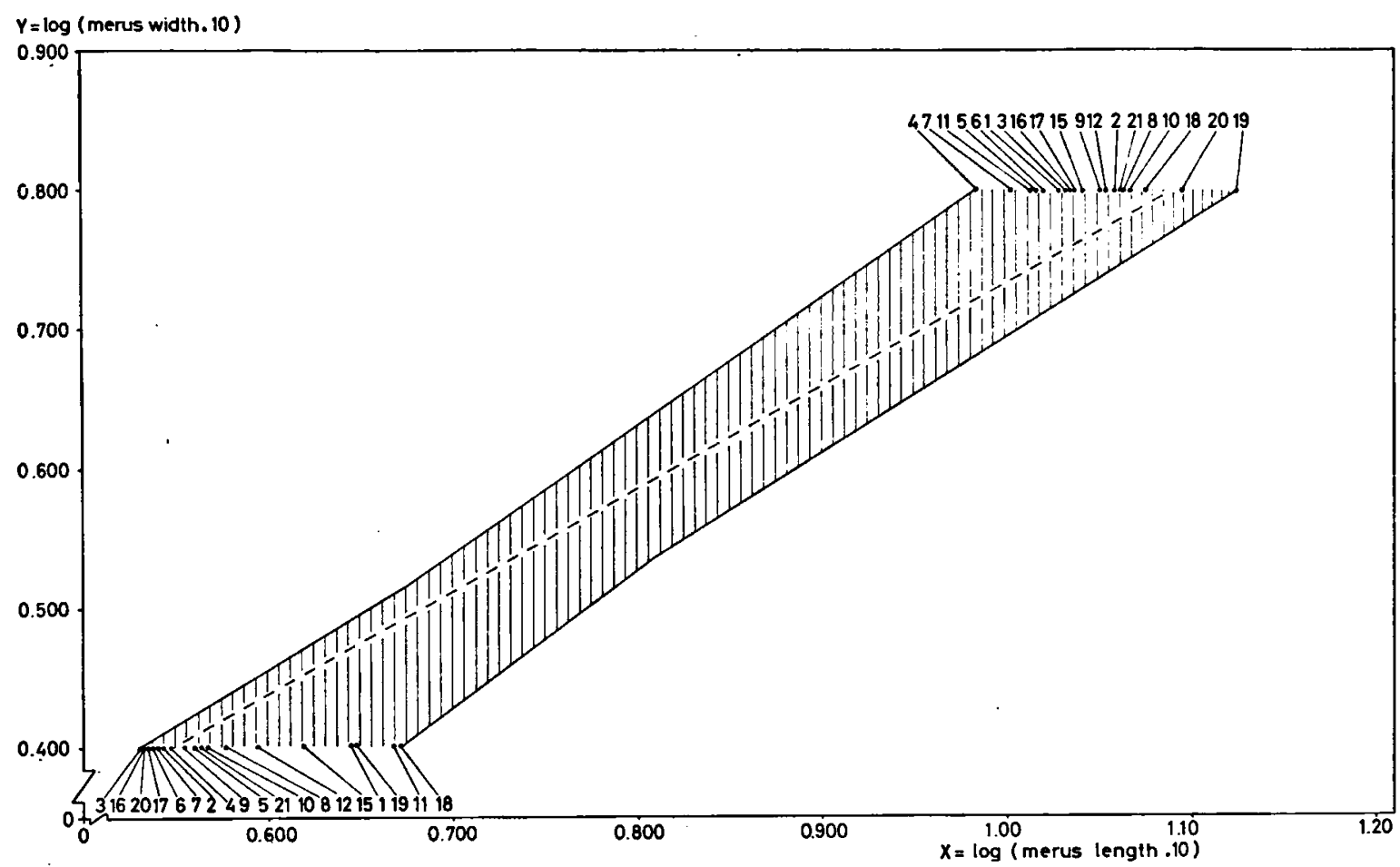

Fig. 3. Initial and end points of the regression lines of $\log$ (merus width . 10) on $\log$ (merus length . 10) of the 21 samples listed in the tables I, II and III. The dashed line indicates a log (merus width . 10) / $\log$ (merus length . 10) ratio of 0.73 . Notice that most of the regression lines cross the ratio 0.73 line.

In every sample there are some animals with a low width/length ratio, together with specimens with a high width/length ratio. Even if in a sample the mean width/length ratio is high, the conclusion cannot be drawn that in that sample all animals have a high width/length ratio. The allometric growth discussed above is partly responsible for this phenomenon.

In a discriminant analysis (based on multiple variance analysis) a number of variables of every single animal are compared with the same variables derived from the other animals investigated.

According to the variable $Y / X$ the animals are divided in two groups: all animals with a ratio $\leqslant 0.73$ are placed in group 1 , whereas all animals with a ratio $>0.73$ are placed in group 2 . The underlying variables used in the discriminant analysis are: type of biotope (rockpool, estuary, intertidal zone of the seashore, freshwater lakes and rivers), sex (male or female), cephalic length, log merus width .10 , and $\log$ merus length .10 . Since some samples lack chlorinity data, and since the reliability of the discriminant analysis is decreasing with increasing number of missing values, the chlorinity of the medium was not used as one of the underlying factors.
The result of the analysis is given in table $\mathrm{V}$. Twenty-five to thirty-five percent of the animals labelled as a member of the first group (i.e., $G$. $d$. celticus according to Sutcliffe, 1972) actually belong to the second group (i.e.,G. d. duebeni), and vice versa. This result tends to confirm that we really have to do with two separate subspecies. According to Mayr (1963) population A and B are separate subspecies when $75 \%$ of population $A$ is different from $97 \%$ of population B. We must keep in mind, however, that in our study we pooled samples from different localities.

In another discriminant analysis the animals are divided in three groups, viz. those originating from typical brackish water biotopes (see table I, samples 1 to $7,9,12,16,17,20$ ), those originating from fresh water in Scotland (table I, samples 8, $10,11,13,14,15)$, and those from fresh water in Ireland and Brittanny (samples 18 and 19). (Sample 21 was too late available to be included in the discriminant analysis.) The variables used are the same as in the first discriminant analysis, and all specimens lacking chlorinity data are rejected.

The results of the comparison of the three groups (compared two by two) are summarized in table VI. This table shows, that when the brackish 
Table IV. The samples of table III rearranged according to decreasing ratio $\bar{Y} / \bar{X}$.

\begin{tabular}{|c|c|c|c|c|c|}
\hline Sample no. & Type of biotope & $n \hat{\delta}$ & $\bar{Y} / \bar{X}$ & $\bar{x} / \bar{y}$ & $\mathrm{Cl}-$ in $\mathrm{mg} / 1$ \\
\hline 4, Norway & rockpool, brackish & 9 & 0.801 & 1.54 & 218 \\
\hline 7 , Canada & seashore, brackish & 15 & 0.792 & 1.62 & 一 \\
\hline 6 , Norway & rockpool, brackish & 25 & 0.775 & 1.63 & 4,500 \\
\hline 5, Norway & estuary, brackish & 17 & 0.774 & 1.68 & 4 \\
\hline 16, Brittany & rockpool, brackish & 54 & 0.771 & 1.63 & 1,450 \\
\hline 3, Norway & rockpool, brackish & 5 & 0.768 & 1.77 & 34 \\
\hline 17 , Brittany & rockpool, brackish & 8 & 0.766 & 1.65 & 1,450 \\
\hline 9, Scotland & rockpool, brackish & 4 & 0.755 & 1.72 & 7,800 \\
\hline 2, Norway & rockpool, brackish & 12 & 0.752 & 1.82 & 12,800 \\
\hline 12 , Scotland & rockpool, brackish & 14 & 0.748 & 1.72 & 120 \\
\hline 21 , Ireland & rockpool, brackish & 18 & 0.746 & 1.65 & 10,800 \\
\hline 14, Scotland & river, fresh & 2 & 0.744 & 1.87 & 20 \\
\hline 10 , Scotland & river, fresh & 1 & 0.735 & 1.83 & 15 \\
\hline 8 , Scotland & river, fresh & 9 & 0.735 & 1.86 & 33 \\
\hline 15, Scotland & river, fresh & 2 & 0.729 & 1.68 & 26 \\
\hline 1, Norway & ditch near fake, brackish & 20 & 0.728 & 1.72 & 1,120 \\
\hline 20, Ireland & rockpool, brackish & 24 & 0.722 & 1.78 & 一 \\
\hline 13, Scotland & river, fresh & 1 & 0.713 & 1.71 & 24 \\
\hline 19 , Ireland & lake. fresh & 5 & 0.702 & 2.10 & - \\
\hline 18, Brittany & river, fresh & 40 & 0.692 & 1.90 & 15 \\
\hline 11, Scotland & river, fresh & 2 & 0.662 & 1.81 & 15 \\
\hline
\end{tabular}

water specimens are compared with the freshwater ones, the latter, whether they are from Scotland or from Ireland and Brittany, show no great overlap with the brackish water animals. The two freshwater groups (Scotland vs. Ireland and Brittany) have an overlap of about $15 \%$. This means, that the brackish water animals are different from both groups of freshwater animals, but that also a considerable difference exists be-

Table V. Results of the discriminant analysis in which group 1 consists of $G$.duebeni specimens with a ratio $Y / X \leqslant 0.73$, and group 2 consists of specimens with a $Y / X>0.73$. For further explanation see section III.

Actual group Predicted group membership

\begin{tabular}{cc}
\hline Group 1 & Group 2 \\
61 & 15 \\
133 & 385 \\
\hline
\end{tabular}

tween the two groups of freshwater specimens.

The following conclusions can be drawn from our analysis of the variation in merus dimensions of $G$. duebeni populations in Europe and Canada: 1. Neither the ratio $\bar{x} \bar{y}$, as proposed by Pinkster et al. (1970), nor the ratio $\bar{Y} / \bar{X}$, as proposed by Sutcliffe (1972), can be used as a main diagnostic character in distinguishing the subspecies $G$. $d$. duebeni from the subspecies $G$. $d$. celticus.

2. A discriminant analysis of the samples from 20 localities has shown, that there is about $25 \%$ overlap between freshwater and brackish water populations when the variables sex, type of biotope, cephalic length, merus length, and merus width of the two groups are compared with each other. This means, that a subspecific status of the brackish water and the freshwater populations cannot be rejected (Mayr, 1963).

Table VI. Results of the discriminant analysis in which $G$. duebeni specimens are divided into three groups. The three groups considered are: specimens from brackish water biotopes, from freshwater biotopes in Scotland, and from freshwater biotopes in Ireland \& Brittany. For further explanation see section III.

Actual group

Predicted group membership

\begin{tabular}{rcc}
\hline Brackish & $\begin{array}{c}\text { Fresh, } \\
\text { Scotland }\end{array}$ & $\begin{array}{c}\text { Fresh, } \\
\text { Ireland \& Brittany }\end{array}$ \\
\hline 406 & 89 & \\
0 & 75 & 80 \\
415 & & 83 \\
0 & & 9 \\
& 66 & 71 \\
\hline
\end{tabular}




\section{DISTRIBUTION OF G. DUEBENI}

\section{1. G. duebeni populations in Brittany}

In July and September 1972 a survey along the Atlantic coast of Brittany was made, in order to find the southernmost brackish water population of G. duebeni on the European continent. At the same time, sampling in the northern part of Brittany was done for two reasons: (1) to find some suitable river systems for a detailed study of the differences in morphology in various habitats, and (2) to investigate whether there have been changes in the microdistribution of $G$. duebeni, G. pulex and Echinogammarus berilloni (Catta, 1878) in the river systems thoroughly sampled in 1969 (Pinkster et al., 1970).

In October 1972 those river systems found suitable for a study on the differences in morphology in $G$. duebeni have been examined again. The river systems were divided in two groups, viz. A. River systems with $G$. duebeni both in the estuarine part and in the limnic part of the river (table VII, systems 1-2, 4-9), and river systems with $G$. duebeni only in the limnic part of the river (table VII, system 3 ).

B. River systems with $G$. duebeni, G. pulex and $E$. berilloni. These river systems are all located inland (table VII, systems 11, 12 and 13).

A third type of river system has also been investigated, viz. a river system with $G$. duebeni in the estuarine part of the river, and both $G$. duebeni and $G$. pulex in the limnic part of the river. All but one of the samples containing $G$. duebeni in this case were too small for statistical treatment, but remarkable is, that in this river system (table VII, system 10) G. duebeni is found more downstream than $G$. pulex, which inhabits the spring zone of the river.

A difference between the present work in Brittany, and the work of Sutcliffe (1972) is, that compared with Sutcliffe we used much more samples (out of a total of 59 samples 48 were used in the biometrical analysis), and that the average number of individuals in each sample was lower. Furthermore we had no previous knowledge about the osmoregulatory capacities of the animals, so we had not labelled them on these grounds as belonging to the subspecies duebeni or celticus.

In the map (fig. 4) the brackish and freshwater stations at which $G$. duebeni was sampled are indicated. It shows, that the southernmost limit of G. duebeni in rockpools is at Pointe de Brézellac,
$25 \mathrm{~km}$ west of Douarnenez (Finistère-S.), while the southernmost locality where $G$. duebeni is found in a small trickle on the beach is at St. Nic, $15 \mathrm{~km}$ north of Douarnenez.

In the southern part of its distribution area $G$. duebeni occurs only in those rockpools, that are protected fairly well against the sunshine, i.e. rockpools at the northern slopes of cliffs, and in caves. Gradually the niche of $G$. duebeni is occupied by several Chaetogammarus species, by Talitridae, and by Melita palmata (Montagu, 1804).

The microzoogeographical analysis of the river systems investigated by Pinkster et al. (1970) revealed, that basically nothing has changed since 1969. In 2 out of the 154 stations $G$. pulex has replaced $G$. duebeni celticus, but also in 2 stations previously inhabited by $G$. pulex now $G$. $d$. celticus was found. Quantitative differences in the relative abundancy of the species are not found, but this might easily be caused by the sampling method used.

From our 1972 survey we have no evidence that the competitive exclusion of $G$. pulex and $G$. duebeni (cf. Dennert, 1974) resulted in the advantage of $G$. pulex. A lapse of three years, however, may have been too short to demonstrate such a farreaching ecological process as competitive replacement.

In four of the six stations with $G . d$. duebeni, indicated by Pinkster et al. (1970: 121, fig. 2), we found $G$. duebeni closely resembling the other freshwater populations found in Brittany. Due to the unreliability of the measurements of Pinkster et al. (1970), erroneously these animals might have been considered G.d.duebeni.

The data on the distribution of $G$. duebeni in the other river systems investigated are to be found in the map of Brittany (fig. 4) and in diagram in fig. 5. In this diagram the ten river systems located near the sea are represented by straight lines running from the spring zone to the estuaries. The three river systems situated completely inland are drawn separately. Indicated in fig. 5 are the values for the ratio $\bar{Y} / \bar{X}$, and the occurrence of other gammarids in the river systems concerned. In the estuaries all the sampling was done at low tide, but the occurrence of typically euryhaline species [ $G$. crinicornis Stock, 1966, G. zaddachi Sexton, 1912, G. chevreuxi Sexton, 1913, Gammarellus angulosus (Rathke, 1843), Chaetogammarus marinus (Leach, 1815), and Corophium volutator (Pallas, 1766)] showed, that although the ion content of the water during the sampling was relatively low 


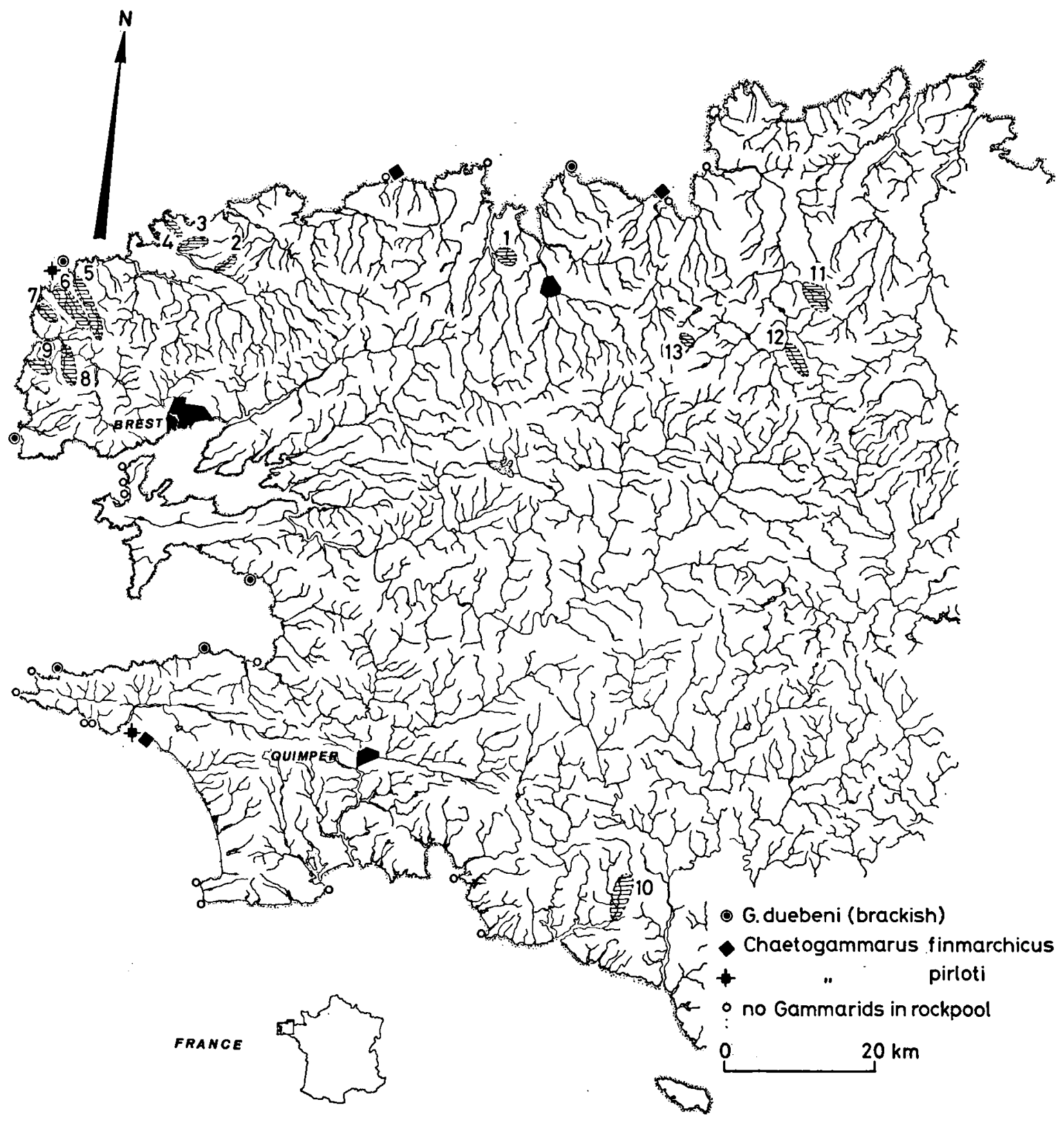

Fig. 4. Map of Brittany with the location of the river systems 1-13 of table VII. Also indicated are the samples from brackish water habitats investigated in 1972. For further information see section IV. 1.

(due to run-off of the river at low tide), we had to do with typically mixohaline water.

Before dealing with the problem whether there are differences in merus dimensions in Brittany, and what causes these differences, the importance of this feature in the context of the work done by Pinkster et al. (1970) and Sutcliffe (1972) must be considered.

According to Pinkster et al. (1970) a population belongs to the subspecies $G$. $d$. celticus when the merus length/width ratio is $>2$, and to the subspecies $G$. d. duebeni when this ratio is $<2$. When using this diagnostic character without any further comment, the subspecies duebeni is found in nearly all the samples (see table VII).

The difference between our results, and those published by Pinkster et al. (1970) can be explained by the fact, that we took our measure- 


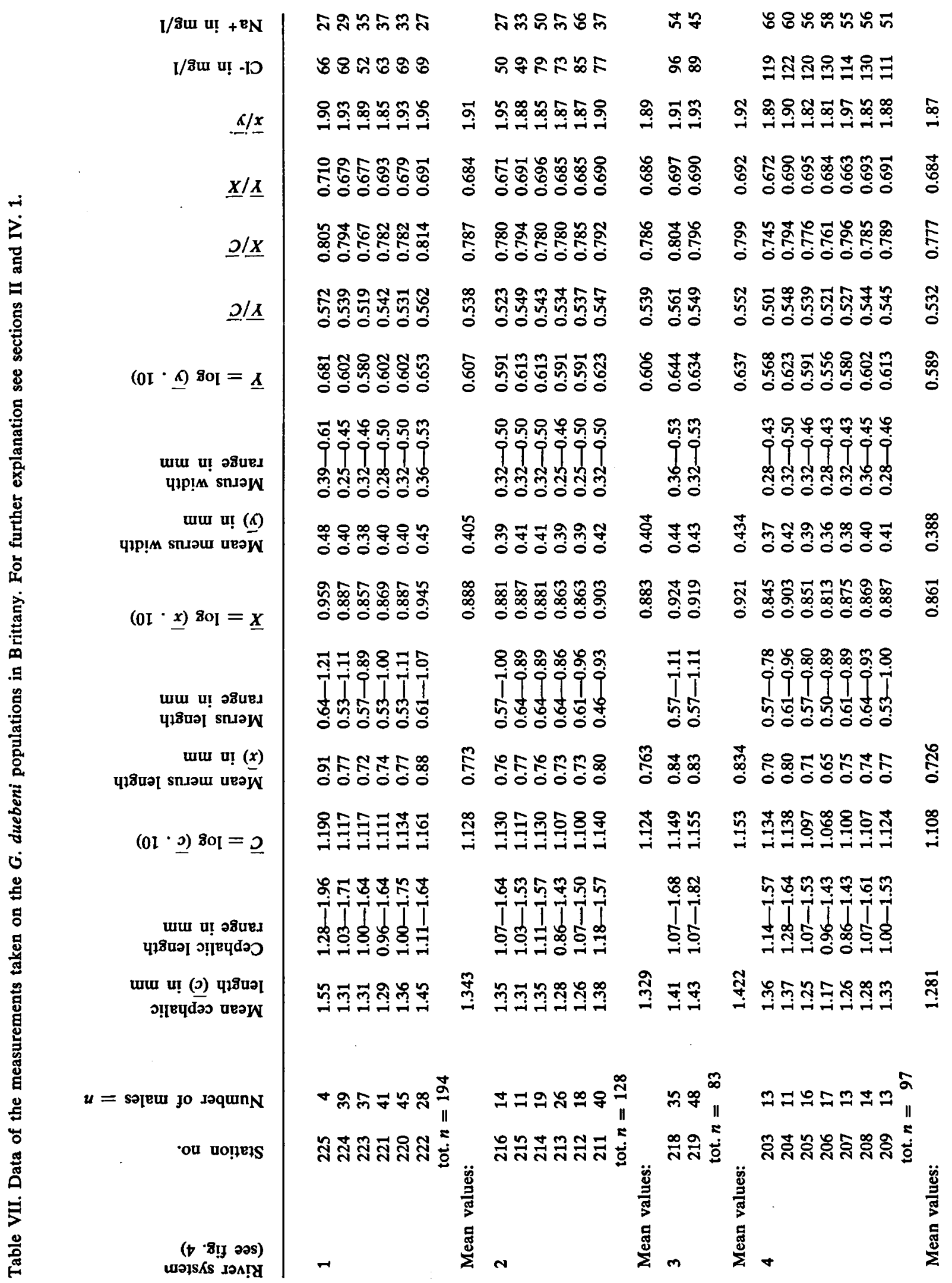



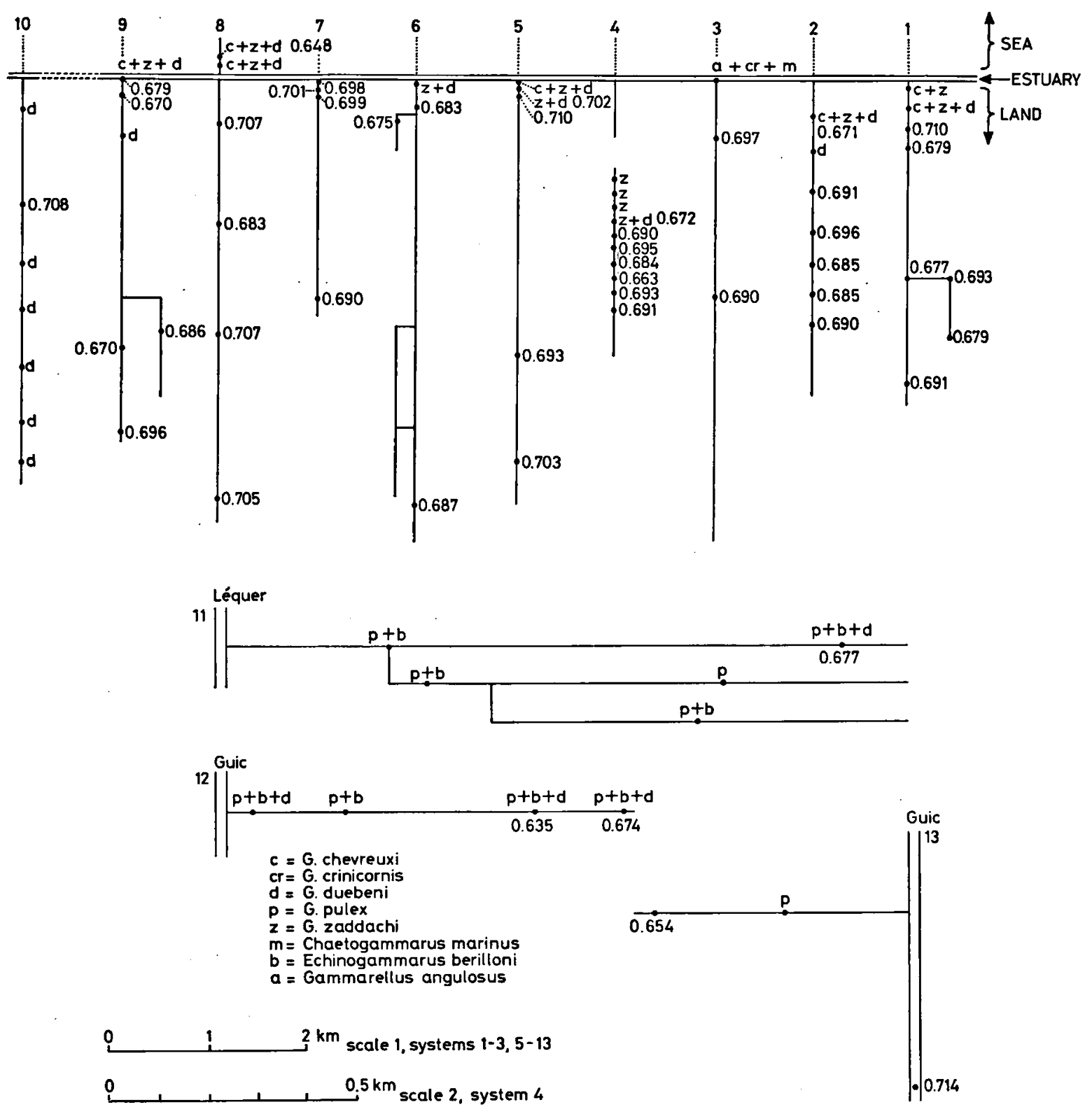

Fig. 5. Diagram representing the river systems mentioned in fig. 4 and table VII. At the localities with G.duebeni, used in the biometrical analysis, the ratio $\bar{Y} / \bar{X}$ is indicated. When present, other gammarid species are indicated as well.

ments on flat, mounted slides, while Pinkster et al. (1970) took their measurements on the entire animal. In preserved, entire animals the legs almost never are in a horizontal plane, thus making the measurements (and especially those of the merus width) inaccurate. Therefore it is better to compare our results with those of Sutcliffe (1972), who also worked with slides, and who based his diagnosis on the ratio $\log$ (merus width . 10)/log (merus length . 10).
According to Sutcliffe a population belongs to celticus at a mean ratio $\leqslant 0.73$, and to duebeni at a mean ratio $>0.73$. In table VII it is shown, that now we must consider our populations from Brittany all belonging to $G$. $d$. celticus. Table VII also shows some differences between the $G$. duebeni populations in Brittany, and the Irish and Scottish populations described by Sutcliffe (1972), viz.:

- the range of the merus width/length ratio is much wider in our samples than in Sutcliffe's; 
- the mean ratio for all the samples in Brittany is 0.688 ; the mean ratio given by Sutcliffe for $G$. $d$. celticus is 0.72 . The differences found cannot be caused by the use of larger animals. According to table II larger animals tend to have a relatively narrower merus. This phenomenon, which is the result of allometric growth of the merus, is discussed earlier by Sutcliffe (1972). On the whole, our samples exist of animals of an average size.

No correlation could be found between the merus dimensions and the type of biotope. In all river systems (see fig. 5) there is a complete random distribution of the ratio $\bar{Y} / \bar{X}$. The expectancy, that the $G$. duebeni populations in the more saline parts of a river system have a relatively wide merus was not affirmed. Most probably the animals found in estuaries have come there as the result of organic drift. Observing figs. 4 and 5 it also becomes clear, that no distinct correlation (clinal variation) exists between the merus dimensions and the geographical position of the river systems in Brittany. From northeast to southwest there is a slight tendency towards a reduction of the merus width/length ratio, in other words the merus is somewhat narrower in the western part of Brittany than it is in the eastern part. Referring to the differences found in Scotland between populations much closer together (see section IV. 3), it seems impossible to draw any far-reaching conclusion with regard to this point.

Four conclusions can be drawn from our observations in Brittany:

1. G. duebeni is found in rockpools and small cliffstreams some $100 \mathrm{~km}$ more to the south than was known till now (Pinkster et al., 1970). Localities with $G$. duebeni in rockpools and cliffstreams are very scattered along the coast and occur exclusively on strongly shaded spots. The latter fact most probably protects the animals from too high summer temperatures.

2. In a relatively short time (three years) nearly no changes have occurred in the microdistribution of the gammarids in Brittany.

3. In Brittanny no correlation exists between the dimensions of the fifth walking leg and the more or less seaward location of the station. A slight clinal variation is found from northeast to southwest; in this cline the merus becomes somewhat narrower in the west.

4. Since the merus width/length ratio in Brittanny is lower than in Ireland (also $G$. $d$. celticus) and Scotland (G. $d$. duebeni, see section IV. 3), the suggestion of Sutcliffe (1972), that a clinal variation exists from the north to the south must be rejected.

\section{2. G. duebeni populations in Norway}

The G. duebeni samples from Norway have been collected in habitats typical for euryhaline animals. From six populations (see fig. 6) the relative dimensions of the merus of the males were determined. The results of the measurements are given in tables III and IV.

It shows, that the animals from these populations have a relatively wide merus, except the Borrevann population. In this inland locality, originally discovered by $\emptyset$ kland (1959), the merus is much narrower. Still, based on the merus dimensions, and the type of biotope, all the Norwegian samples can be labelled $G$. d. duebeni.

\section{3. G. duebeni populations in Scotland}

A survey trip, made in March 1972 all along the northeast, north, and west coasts of Scotland, revealed that only in two peninsulas, already mentioned by Hynes (1954) and Sutcliffe (1967a), freshwater populations of $G$. duebeni are found (see fig. 7). In these two peninsulas (Kintyre, Argyll, and the Rinns of Galloway, Wigtown) rather intense sampling was done, thus making a microzoogeographical analysis possible. From eight stations in Scotland the relative dimensions of the merus were determined. The results are presented in table III.

Probably due to very heavy rainfall in March 1972, the rivers in Kintyre were very swollen, whereas the riverbanks were sometimes completely eroded. For this reason mostly small samples were obtained. Nevertheless we found that the distribution in the Kintyre peninsula (fig. 8) is equal to the situation described by Sutcliffe (1967a).

In the Rinns of Galloway (fig. 9), G. pulex was found in the southern part of the peninsula in rivulets close to the seashore. G. duebeni was found in the northern part in the same kind of rivulets. The peninsula is separated from the rest of Scotland by a wide zone without any Gammarus species in the rivers. This might be caused by the high concentration of humus acids in those rivers. In the Rinns of Galloway, along the coast, in suitable brackish water habitats such as rockpools, $G$. duebeni is found as well.

The situation found in the Rinns of Galloway is in complete contradiction to the theory of Pinkster et al. (1970), according to which G. duebeni 


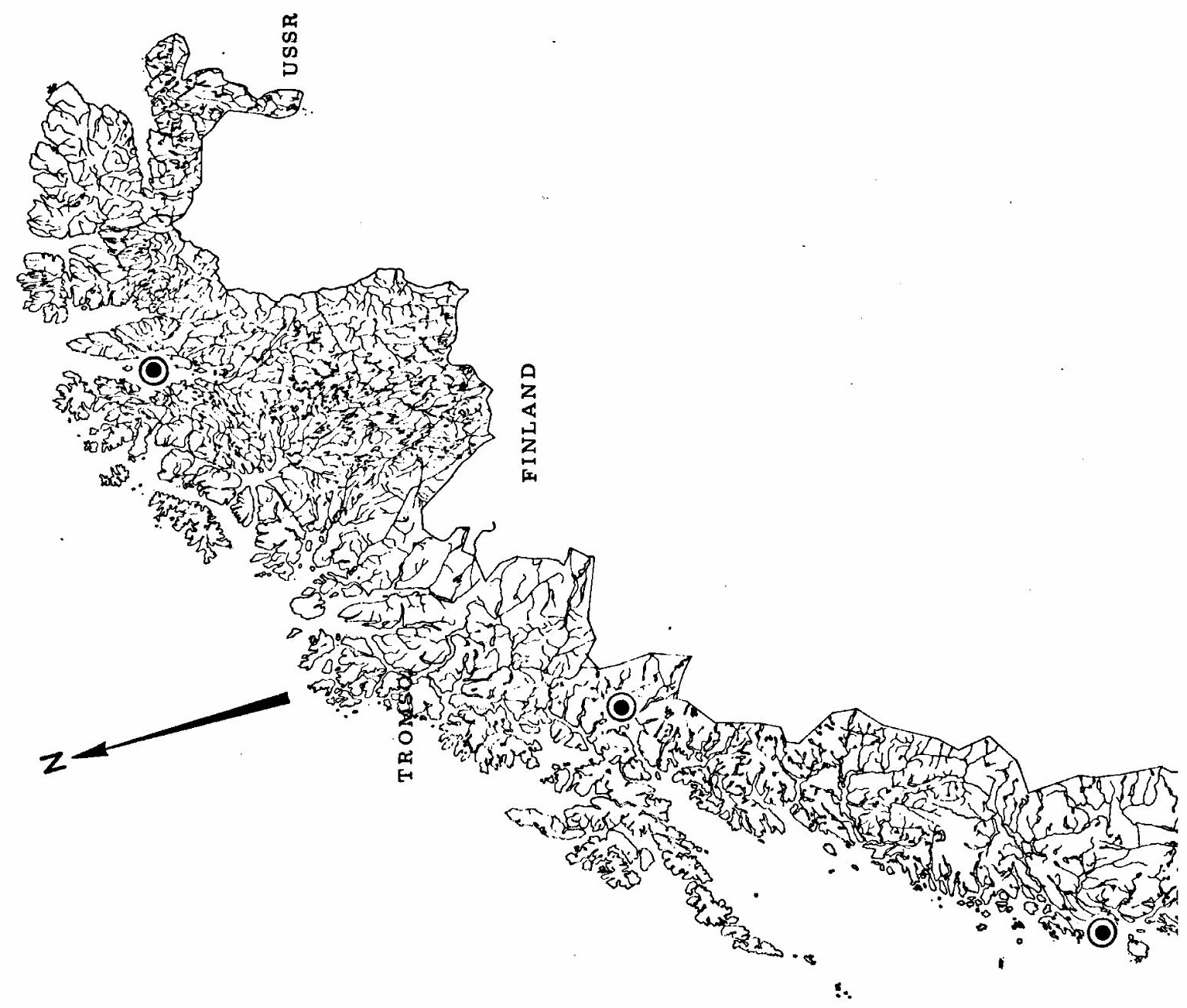




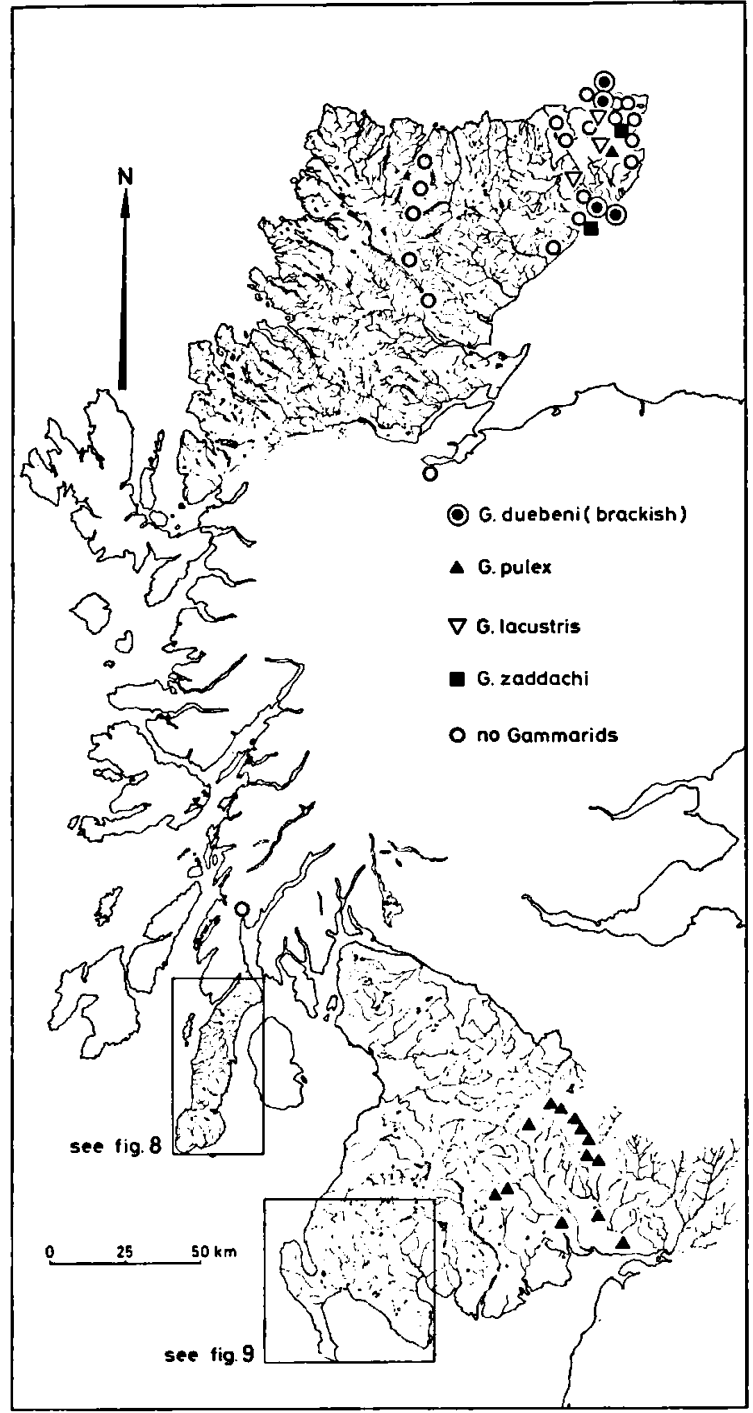

Fig. 7. Map of Scotland, with the distribution of gammarids in the northeastern and southwestern part.

Kintyre peninsula and the Rinns of Galloway on separate maps.

gradually is expelled from fresh water by $G$. pulex. If this were true, $G$. pulex would have been found in that part of the peninsula that borders on the mainland, i.e. in the northern part. The suggestion of Sutcliffe (1967a, 1971a), that G. duebeni is invading freshwater habitats seems to be more convincing in this particular situation.

From our survey in Scotland, we may draw the conclusion, that both in the Rinns of Galloway and the Kintyre peninsula the brackish water populations have a higher $\bar{Y} / \bar{X}$ ratio than the freshwater populations. Some of the freshwater popu-

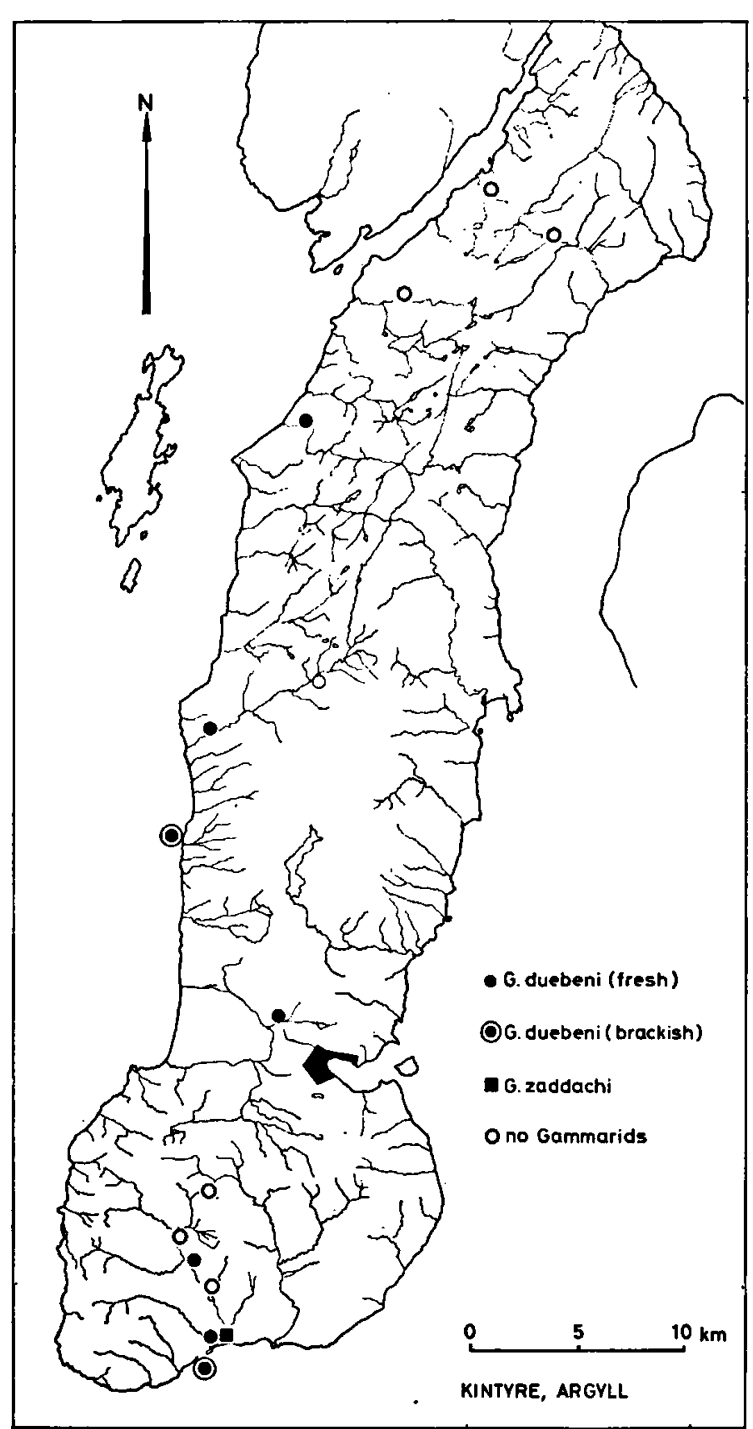

Fig. 8. Distribution of gammarids in Kintyre, Argyll.

lations, however, have a $Y / X$ ratio of about the same magnitude as found in the brackish water populations in Ireland (see table III). Considering the high $\bar{Y} / \bar{X}$ ratios found in Scotland, and the distribution of $G$. duebeni and $G$. pulex in the Rinns of Galloway, it seems likely that the $G$. duebeni populations in Scotland only recently have invaded fresh inland waters and belong to the subspecies $G$. $d$. duebeni. The physiological experiments of Sutcliffe (1971 a \& b), and the ecological experiments of Dennert (1974) support this conclusion. 


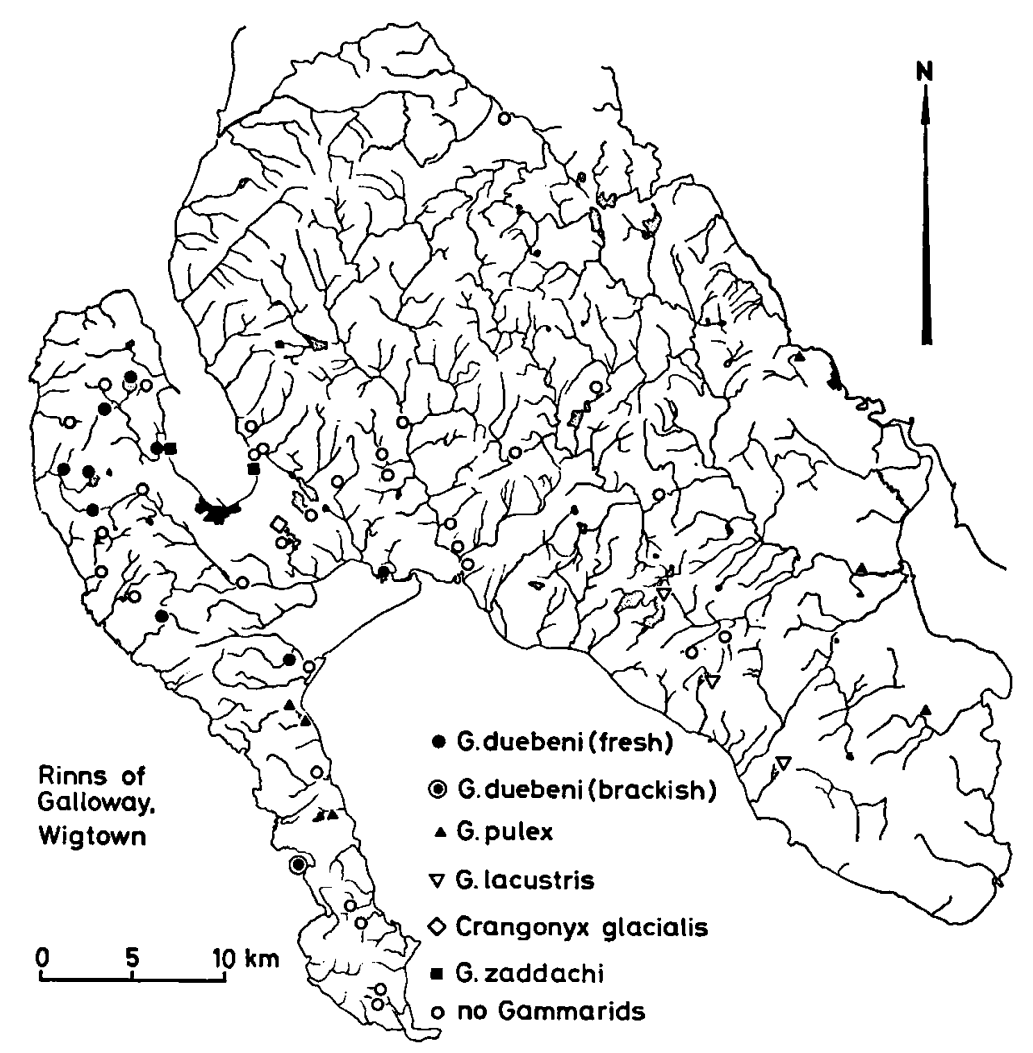

Fig. 9. Distribution of gammarids in the Rinns of Galloway, Wigtown.

\section{4. G. duebeni populations in Ireland}

The distribution of G. duebeni in Ireland is discussed thoroughly by Sutcliffe (1967a, 1972) and Pinkster et al. (1970). In order to compare the Irish populations with the $G$. duebeni populations from Norway, Scotland and Brittany, investigated in this paper, three samples from Ireland have been treated statistically (see tables III and IV). Also in Ireland the brackish water populations have a wider merus than the freshwater populations. In agreement with Pinkster et al. (1970) and Sutcliffe (1972) we may label the freshwater populations in Ireland $G$. d. celticus, and the rockpool populations G. d. duebeni.

\section{DISCUSSION}

Our data on the distribution of G. duebeni, and our data on the $Y / X$ ratios of the brackish water and freshwater populations of this species have shown the little usefulness of the ratio merus width/merus length (either expressed according to Sutcliffe, 1972, or to Pinkster et al., 1970) as the main diagnostic character for the distinction of the subspecies duebeni and celticus.

Differenoes in physiology (Hynes, 1954; Sutcliffe, 1967b, 1971 a \& b; Sutcliffe \& Shaw, 1968), in ecology (Hynes, 1954, 1955; Økland, 1959; Pinkster et al., 1970; Dennert, 1974), and in morphology (Pinkster et al., 1970; Sutcliffe, 1972) between the separate $G$. duebeni populations cannot be denied.

Hynes (1954), and Sutcliffe \& Shaw (1968) have considered the separate $G$. duebeni populations from Great Britain and Ireland as physiological races. Superficially this may seem to be an attractive solution for the question which taxonomical status the $G$. duebeni populations in fresh and brackish waters have. The existing morphological differences (Pinkster et al., 1970; Sutcliffe, 1972), however, make the situation more complex.

The discriminant analysis carried out in this paper (section III), the zoogeographical data presented 
by Pinkster et al. (1970) and in section IV of the present paper, and the differences in competitive potency between brackish water $G$. duebeni and G. duebeni from Brittany (Dennert, 1974), give strong evidence for the actual existence of the two subspecies $G$. d. duebeni and $G$. d. celticus. In our present concept the distribution of $G$. $d$. celticus is restricted to the rivers and lakes in Brittany and Ireland. The freshwater populations of Britain must only recently have invaded inland waters. In some places geographical isolation has resulted in slight morphological differences between these populations and the populations in the brackish water habitats (cf. section III, and IV. 3), but the physiological differences are still phenotypic (Sutcliffe, 1971 a \& b).

The morphological differences between nearby located stations in Scotland and between the inland populations and the brackish water populations, can be explained by the founders principle (Mayr, 1963). According to Mayr, smaller groups of animals, separated from the main population, may evolve separately. In situations where these groups of animals live in the periphery of the distribution area of the species, or in marginal biotopes, competition and adaptation will lead to character displacement (Miller, 1967). This is most clearly demonstrated when populations, not widely separated geographically, but in different habitats, show differences much greater than the differences between, for instance, a rockpool population in Norway, and a rockpool population in Brittany.

On the other hand, sometimes $G$. duebeni populations from different biotopes show identical morphological features. In Brittany we find specimens without morphological differences of any importance in the upper reaches, and in the estuary of the same river system (cf. table VII). As in these rivers very large populations of $G$. duebeni are found, this phenomenon can be explained by a strong gene flow from the freshwater population to the population in the estuary. This gene flow may be caused by a combination of organic drift, and the occurrence of matings between downstream drifters and the animals originally inhabiting the estuary. In the same way, the morphology of $G$. duebeni in the Kintyre peninsula and in the Rinns of Galloway can be explained by a gene flow originating from the (abundant) brackish water populations in these regions.

The role of $G$. pulex in the evolution of the $G$. duebeni populations in Europe seems to be partial- ly different from the role proposed by Pinkster et al. (1970). Dennert (1974) has shown, that not only $G$. pulex is able to compete $G$. $d$. celticus successfully, but that $G$. d. duebeni is able to compete G. pulex even better. Hence in Brittany (and in Ireland provided that $G$. pulex would have been present) G. pulex can compete the inland populations of $G$. duebeni, while in the rest of its distribution area $G$. duebeni is able to compete $G$. pulex while invading fresh waters. The observations of Sutcliffe $(1967 \mathrm{~b}, 1971 \mathrm{~b})$ on the mutual resemblance of the osmoregulatory potencies of the Kintyre, Rinns of Galloway, and rockpool populations of $G$. duebeni likewise support the theory that in the British Isles G. duebeni is a recent invader in the freshwater biotopes. The interactions mentioned above, existing between the different $G$. duebeni populations and $G$. pulex are given in diagram in fig. 10.

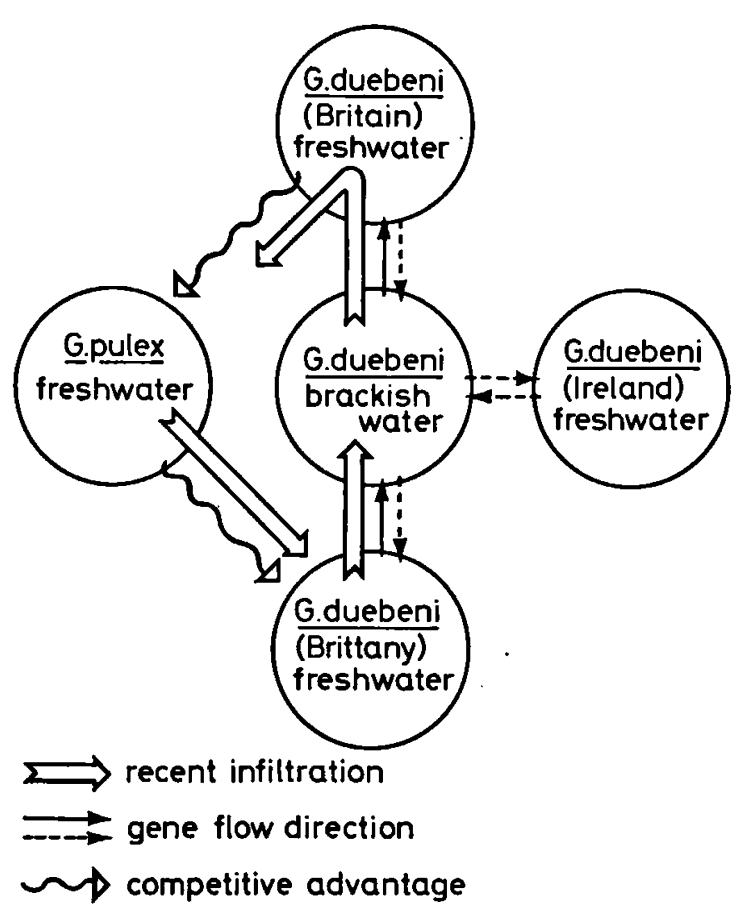

Fig. 10. Diagram showing the relationships between $G$. duebeni from brackish water, and from freshwater biotopes, and $G$. pulex. A recent infiltration of one $G$. duebeni population in a locality previously inhabited by another $G$. duebeni population results in a stronger gene flow in the infiltration direction than vice versa. A relatively strong gene flow is indicated by a solid arrow, a relatively weak gene flow is indicated by a dashed arrow. The competitive advantage is indicated according to Dennert, 1974; G. pulex has an advantage on the old inland $G$. duebeni populations (Brittany), but the recent $G$. duebeni invaders in Britain have an advantage on G. pulex. 
Sutcliffe (1972) suggested, that there might be a clinal variation in the relative merus dimensions of G. duebeni. Apart from the fact, that in the subspecies concept this is less likely, our present investigations give no evidence for this theory. The fact, that in the northern part of its distribution area $G$. duebeni populations are found with on the whole a rather wide merus, coincides with the fact that in these regions $G$. duebeni is exclusively found in typical brackish water habitats. In the southern part of its distribution area $G$. duebeni occupies a wider range of biotopes. In this part of its distribution area, populations are found with a wide, or with a narrow merus. As in this southern part of the distribution area of $G$. duebeni the changes in merus dimension are rather abrupt and scattered, neither a cline in north-south direction, nor a cline in east-west direction is recognizable.

\section{ACKNOWLEDGEMENTS}

The author is indebted to Drs. A. M. J. Maasen and Drs. A. L. Dennert for their assistance during the fieldwork and for part of the identifications, to a team of M.Sc. students of the University of Amsterdam, led by Prof. Dr. J. H. Stock for the samples they collected in Brittany, to the Station Biologique, Roscoff, France, where members of our team received hospitality during the fieldwork, to Dr. J. $\varnothing$ kland, Dr. V. Gotto and Dr. V. J. Steele for the samples they put at his disposal, and to Drs. B. Niemuller and Mr. H. Olofsen for their statistical advices. Furthermore the author likes to thank Prof. J. H. Stock, Dr. S. Pinkster, Drs. F. Peeters, and Dr. S. van der Spoel for their valuable advices and their critical comments on the manuscript of this paper. The Royal Netherlands' Academy of Sciences, and the Netherlands' Organization for Pure Scientific Research (ZWO) are acknowledged for grants, making the fieldwork possible in Norway, Scotland, and Brittany.

\section{LITERATURE}

Beld, F. A. J. van den, 1973. Cycles annuels de Gammarus duebeni duebeni Liljeborg, 1852, et de Gammarus pulex pulex (Linné, 1758) le long de la côte française du Boulonnais. Bull. zool. Mus. Univ. Amsterdam, 3 (13): 79-98.

DENNERT, H. G., 1973. Notes on some euryhaline Gammarids (Crustacea, Amphipoda) from the west-coast of Norway. Bijdr. Dierk., 43 (2): 160-172.

,- 1974 . Tolerance differences and interspecific competition in three members of the amphipod genus Gammarus. Bijdr. Dierk., 44 (1): 83-99.

Dennert, H. G., A. L. Dennert, P. Kant, S. Pinkster \& J. H. STock, 1969. Upstream and downstream migrations in relation to the reproductive cycle and to environmental factors in the amphipod, Gammarus zaddachi. Bijdr. Dierk., $39: 11-43$.

HyNES, H. B. N., 1954. The ecology of Gammarus duebeni Lilljeborg and its occurrence in fresh water in western Britain. J. anim. Ecol., 23 : 38-84.

,- 1955 . Distribution of some freshwater amphipods in Britain. Verh. int. Verein. theor. angew. Limnol., 12 : $620-628$.

MAYR, E., 1963. Animal species and evolution: i-xiv, 1797. (Belknap press of Harvard University Press, Cambridge, Mass.).

Miller, R. S., 1967. Pattern and process in competition. Adv. ecol. Res., $4: 1-74$.

Nie, N., D. H. Bent \& C. Hadlai Hull, 1970-1973. SPSS, statistical package for the social sciences (1970): i-xx, 1-343 (McGraw-Hill, New York etc.). SPSS6000 , update manual version 5.5 (1973): [i-ii], $\mathrm{i}-$ vii, [1-87] (Vogelback Computing Center, Northwestern University).

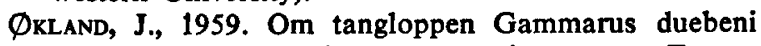
som ble funnet ved Borrevann i sommer. Fauna, Oslo, 12 (1): 1-14.

Pinkster, S., A. L. Dennert, B. Stock \& J. H. Stock, 1970. The problem of European freshwater populations of Gammarus duebeni Liljeborg, 1852. Bijdr.
Dierk., 40 (2) : 116-147.

SEXTON, E. W., 1924. The moulting and growth-stages of Gammarus, with descriptions of the normals and intersexes of G. chevreuxi. J. Mar. Biol. Ass. U. K., 13 (2) : $340-401$, text-figs. $1-4$, pls. I-XXI.

Steele, D. H. \& V. J. Steele, 1969. The biology of Gammarus (Crustacea, Amphipoda) in the northwestern Atlantic. I. Gammarus duebeni Lillj. Can. J. Zool., 47 : $235-244$.

Stock, J. H. \& S. Pinkster, 1970. Irish and French freshwater populations of Gammarus duebeni subspecifically different from brackish water populations. Nature, Lond., 228 : 874-875.

SutClifFe, D. W., 1967a. A re-examination of observations on the distribution of Gammarus duebeni Lilljeborg in relation to the salt content in fresh water. J. anim. Ecol., 36 : 579-597.

,$- 1967 \mathrm{~b}$. Sodium regulation in the amphipod Gammarus duebeni from brackish-water and freshwater localities in Britain. J. exp. Biol., 46 : 529-550.

,- 1971 a. Sodium influx and loss in freshwater and brackish-water populations of the amphipod Gammarus duebeni Lilljeborg. J. exp. Biol., 54 : 255-268.

,- 1971 b. Regulation of water and some ions in Gammarids (Amphipoda). I. Gammarus duebeni Lilljeborg from brackish water and fresh water. J. exp. Biol., 55 : 325-344.

- , 1972. An examination of subspecific differences in the merus of the fifth walking leg of the amphipod Gammarus duebeni Lilljeborg. Freshwat. Biol., 2 : 203216.

SưtClifFe, D. W. \& J. SHAw, 1968. Sodium regulation in the amphipod Gammarus duebeni Lilljeborg from freshwater localities in Ireland. J. exp. Biol., 48 : $339-358$.

WiJvekate, M. L., 1963. Verklarende statistiek. Het onderscheiden van toeval, schijn en werkelijkheid in cijfermateriaal: 1-232 (Het Spectrum, Utrecht). 